\title{
Effectiveness of Interactive Multimedia Based Learning Model in Engineering Mechanics
}

\author{
Hamonangan Tambunan ${ }^{1} \&$ Efendi Napitupulu ${ }^{2}$ \\ ${ }^{1}$ Department of Electrical Engineering Education, State University of Medan, North Sumatra, Indonesia \\ ${ }^{2}$ Department of Civil Engineering Education, State University of Medan, North Sumatra, Indonesia \\ Correspondence: Hamonangan Tambunan, Department of Electrical Engineering Education, State University of \\ Medan. Jl. William Iskandar Psr V Medan Estate, Medan, Indonesia. E-mail: hamtambun@gmail.com
}

Received: March 4, 2016

doi:10.5539/ies.v9n10p155

\begin{abstract}
Now the demand for skilled labor is urgent. Development of skilled labor has been done in various ways either through education and training. Indonesia, especially North Sumatra state nurture some vocational schools that produce graduates which are expected to be ready for working, but have not been able to meet these expectations. Therefore we face how to build a learning that is intended to establish effectively the competence of Vocational Middle School students. In this study, we propose an interactive multimedia-based learning model in teaching engineering mechanic competence. The results of empirical data showed significant evidence supports our proposition. It explores an important issue in developing the learning model of student competence in the field of engineering mechanic.
\end{abstract}

Keywords: learning model, interactive multimedia, engineering mechanic competence

\section{Introduction}

Indonesia strives to improve the competency of the workforce. It is based on the data released by Human Development Index (HDI), which is the level of Indonesian's workforce competence currently on the 108 rank out of 169 countries (People's Welfare Ministry of Indonesia, 2010). Workforce's competence associated with learning in schools. So, increasing workers' competence can be done through improving the quality of teaching in vocational schools. A popular approach in practice is an evident of someone has a competency that can be increased by collaborative problem solving (Kennedy, 1999; Schippmann, 2000; Cowie, 2000; Boyatzis, 2008). Someone who able in transferring and applying knowledge and skills to face the new situation is called the competent person. It is the essence of the qualitative description of its behavior when do the job. This is shown by the skill, the power, the authority, and the finesse on rational action based on the expected events (Mahoney, Cairns \& Farmer, 2003). It is an important criterion of a person has the competence, who contributes to a high value of the level of individual and social life, and makes it as an instrument to deal with the demands and the complex challenges (Rychen, 2002; Putwain \& Symes, 2011).

A competency can be awakened through a variety of learning activities with opportunities for the learners to conduct investigations and experiments (Dooly, 2012; Hicks, 2014). It is also needed another best consideration to assess and to accredit the work-based learning of students in relation to the development of competence (Watkins \& Charles, 2000; Hammer \& Swaffar, 2012). A learning model in the form of practice, which is meaningful as the objects or the concepts used in presenting something, is compatible with this objective. It is done to concretize a theory and also is an analogy and representation of the variables contained in the theory (Hoag, 2001; Juniper, 2000).

Indonesian Educational Ministery (2006) released that all of schools have had ICT equipment for increasing the competence of graduates' purpose, either in the classroom or in the library and laboratories. The importance of developing and utilizing multimedia computer technology in learning is becoming a liability in line with the changes that occur in various areas of human life (Moss, 2006). Effective learning model is needed to achieve the goal in a learning process in line with the learning paradigm, which focuses on teaching the students to learn. In this case the teacher role is as a motivator and facilitator, and need a media to make student can regulate his/her learning. Interactive multimedia is one of the media accordance with these objectives, because of using it 
can arise the student's learning outcomes (Hunt et al., 2001, Damiana \& Almei, 2012). Learning with multimedia can simulate the complex processes and the abstract concepts. Visualization is made interactive which allow learners to change the input variables by entering data or by manipulating visual objects, and can observe the consequences of this change in the visualization (Cai, 2014). The output of variable is visualized in a dynamic way, in running the animation after the manipulation input variables or by changing the object simultaneously for the manipulation of input variables is changed continuously (Bodomer, et al., 2005; Xia, 2011). Thus enabling to develop a learning model which can improve the competence of vocational school graduates.

A permanent change in the form of behavior relatively, as the result of learning, is reinforced through practice (Hegerhahn \& Olson, 2008). It needs to be focused as a form of potential behavioral on what humans do with the information they receive, and what they did after obtaining the discrete information to reach an understanding which gives them the ability (Applying the Model in Practice, 2011; Bridgeland \& Zahavi, 2009). There are four learning themes for these purposes, namely: (1) The importance of the knowledge structure, which help the learners to see how the facts connected to another information they have. (2) Readiness to learn, which consists of mastering simpler skills to allow one to acquire higher skills. (3) The value of intuition in the educational process, in the intellectual techniques used to find out a tentative formulations without going through the analytical steps to determine whether the formulations are valid conclusions or not. (4) The motivation or desire to learn and the teachers' ways to stimulate the learner. Educational experiences that stimulate motivation is the experiences in which learners participate actively dealing with nature (Snook, 2001; Shipton \& Sillince, 2012). Thus it takes multimedia to facilitate student learning.

Multimedia usually refers to the capacity of computers to provide the real-time representations of nearly all existing media and sensory modes of instruction (Anonymous, 2013). Interactive related to two-way communication or more of the components of communication (Dereshiwsky, 2014). Component of communication in interactive multimedia (computer-based) is the relationship between human beings (as users/users of products) and computer (software/applications/products) in a particular file format, usually in the form of a compact disk (Deliyannis, 2012). Thus the product application is expected to have a two-way relationships/ interrelationships between software/applications to the user. Interactivity in multimedia is restricted by (1) The user which involved to interact with an application program, (2) The interactive information applications intended is the users can get only the information they want without having to come up with these all (Morris, 2000). It is used as a basis for developing learning models of engineering mechanics.

The development patterns of the models are proposed for fieldwork. It is the real world abstraction or the representation of the complex events or the systems, in the form of narrative, the mathematical, the graphic or the other symbol which arise from the fact that having a particular arrangement of sequences (Moon, 2004; Patricia, 2009). The model can be used to organize knowledge from various sources and then used as a stimulus for developing hypotheses and build theory into the terms or the conditions, so that it can be applied to the concrete practice or to test the theory (Mioduser \& Dagan, 2007).

The practical function of the models is mean facilitating a communication, or regulating user (algorithm) in decision-making, or planning guidance for managing activities (Brinkerhoff, 2001; Gati \& Tal, 2008). If a model can help the user to understand something thorough process fundamentally and relevant to the theory is said a good model (Bridgeland \& Zahavi, 2009). The benefits of the model for the user, among others are: (1) To explain some aspects of human behavior and interaction, (2) To integrate what is known through observation and research, (3) To simplify complex human processes, (4) To be a guidelines to conduct activities (Köck \& Paramythis, 2011). There are three types of determining the appropriate development, namely (1) Inductive model which is derived from the experience of the learners behavior. This moment is grouped, compared, developed and finally evaluated to ultimately held revisions, (2) Deductive models which begins with the general goal setting, determining criterion, looking for linkages between existing elements/partners, collecting data, formulating of specific objectives, developing and implementing, then proceeding with evaluation and revision, (3) The classical model which is started with some general requirements of the goals, program development, program implementation, evaluation and subsequent revision (Atkinson \& Bostan, 2009). It is used to developed the instructional systematically in identifying, developing, and evaluating a set of materials and strategies in achieving a specific learning goals, in engineering mechanics competence. The result of instructional development is a learning system, namely learning materials and teaching strategies, which are developed empirically and consistent in achieving specific learning goals (Armstrong, Tucker, \& Massad, 2009). This is what makes the basis of the importance of building of the learning model in engineering mechanics lesson. 


\section{Method}

The development of learning model is through five stages, namely learning plan based on competence and structure of learning materials, design and development early product model, validation by experts, testing of the product, and then revise the product. Testing subject is done by three technicians of mechanics, one subject matter experts, one instructional design experts, individual tests through three students, small groups testing by involving twelve of students, and field testing by involving twenty-five of students. The instrument use to find data are questionnaires, interviews, records and documents and then analyzed by descriptive statistic. The steps being taken is started by a preliminary study, planned model, developed model, validated model and tested the IS ME QUEEN learning model, and at the end is to disseminate the model. The effectiveness of instructional model is tested by experimental studies. T-test statistics with $\alpha=0.05$ is used to compare the learning outcomes of students of using the model and the learning outcome of students not used model. The model is called effective, if the learning outcomes of the student who use the model is higher than learning outcomes of student who no use the model significantly.

\section{Results}

IS MI QUEEN learning model is developed to combine learning component in the scheme measures interactive multimedia-based learning. This is a program of computer-assisted learning in face-to-face learning. As much of $30 \%-70 \%$ of the learning material is loaded into the computer as a learning facility. The material was shown live on a screen, so students are grouped into an interaction pattern of students learning to find solutions of the problems by using the diverse sources in the internet facility. The constructivism learning theory become a reference in developing a model which phasizes the student centered learning. The development is done through analysis, design, development, implementation and evaluation of the instructional model.

The need analysis results represent the vocational school require the interactive multimedia-based instructional model especially in the engineering mechanics. Based on the observation, the vocational school in North Sumatra does not have special equipment in engineering mechanics. Likewise that the data obtained show the teachers and the students need for learning tool that allows students to learn, especially in the subjects of engineering mechanics. The results of interviews with 20 students showed that students' school time available to study engineering mechanics completely still not enough. Likewise, the response of the teacher show that it is required an engineering mechanics teaching aids. So the media was developed to enable students can study either engineering mechanics in school or out of school completely.

The variety of models of student-centered learning approaches such as Contextual Teaching Learning (CTL) is combined on the development stage in introducing the topic of learning contextually. Explaining the problems of learning and how to solve the problem is used Problem Based Learning (PBL). It will be performed by the students. Classifying students in group is implementation of Cooperative Learning use. A particular shaping in serving the object of student learning is used Project Based Learning (PBL). And then continued with explanation by student in the class as a discovery response from students (Discovery Learning). This model is named IS MI QUEEN. The flowchart of the model is like Figure 1. 


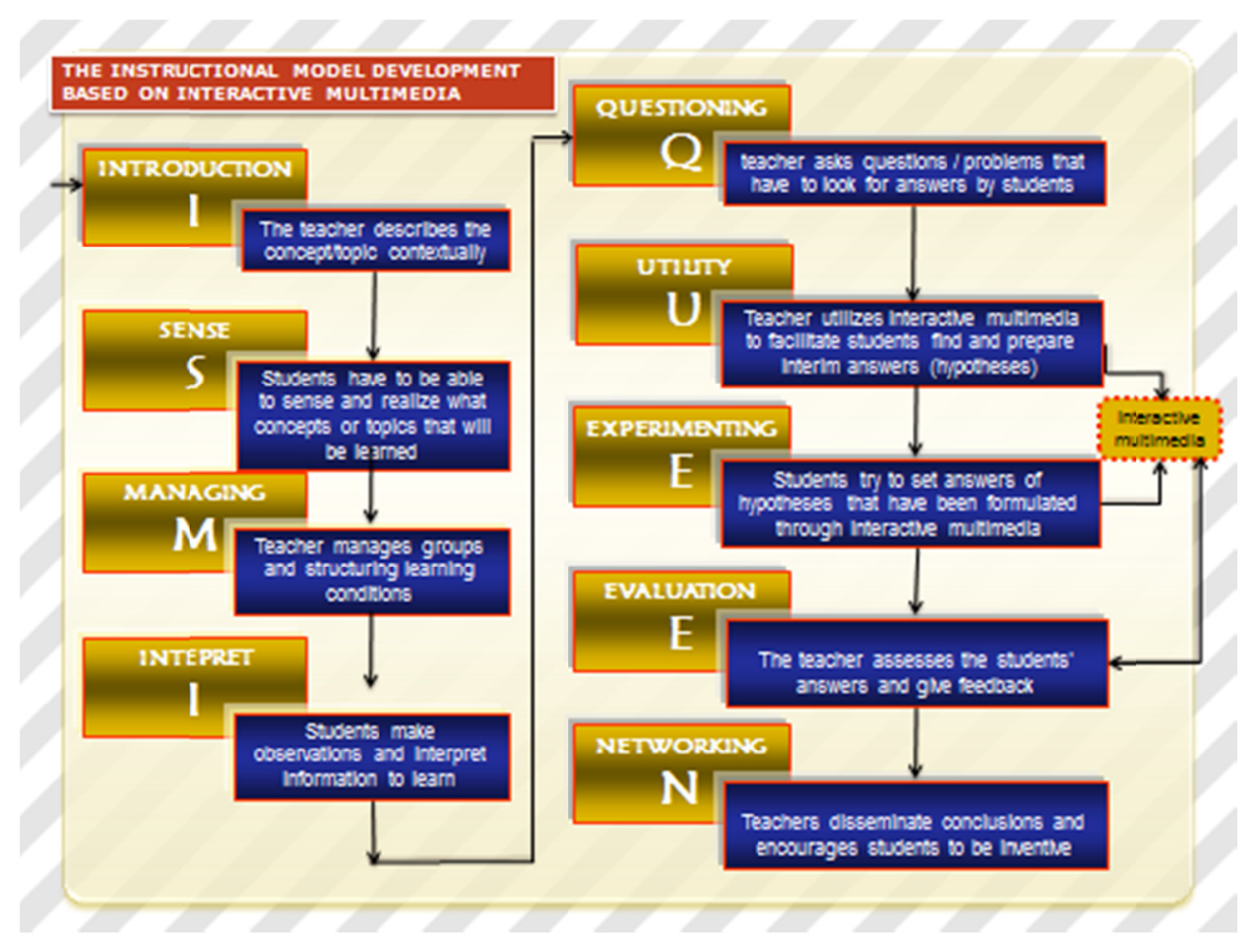

Figure 1. IS MI QUEEN model

The " IS MI QUEEN “ model is built in teaching engineering mechanics with the aim that students will be able to articulate and describe (1) Relative motion; (2) Inertial and non-inertial reference frames; (3) Parameters defining the motion of mechanical systems; (4) Study of the interaction of forces between solids in mechanical systems; (5) Centre of mass and inertia tensor of mechanical systems; (6) Application of the vector theorems of mechanics and interpretation of their results; (7) Newton's laws of motion and conservation principles; (8) Introduction to analytical mechanics as a systematic tool for problem solving; and (9) Use of mechanical simulation software. Each goal is achieved through the nine steps of the learning model.

There are nine steps in the learning model design/ development. At the beginning of the teaching, teacher must always describes each of the scope of which is going to be studied. It is intended for students to have the same perception of the all topic. For example of the using of the learning model in teaching of relative motion is begun by describing and articulating the concept of the relative motion contextually (Introduction). Hereafter, students have sensed and realized that they will learn the motion and forces concepts and its' benefit (Sense). Teacher manages the groups and the structuring learning conditions, by forming the study groups consisting of 4-5 students (Manage). Students observe and interpret the movement and labor performed (Interpret). Students answer what, how and for what the relative motion, accordance teacher ask (Question). Interactive multimedia is used by teachers to help students find and prepare a temporary answer - hypothesis (Utility). Simulation of the relative motion can be shown to the students, which has been available in the media (Experimenting). By using the interactive multimedia, students try to set answers of hypotheses that have been formulated. And it is forwarded to give feedback based on assessing the students' answers (Evaluation). The impetus given to the students to be inventive about motion through the dissemination of conclusions by the teacher (Networking). The nine steps is used in achieving the nine goal of engineering mechanics.

The learning model developed is evaluated by three experts instructional, namely materials expert, software experts (IT) and learning media expert. According to their evaluation the model has been eligible but need to be repaired. Improvement is done by integrating the power point into media. Based on the individual test stages, ie small group testing stage, and field trials at the second stage, is found that (1) The model is well qualified based on subject matter experts in technical mechanics test. The model had satisfied in teaching engineering mechanics as many of $70.83 \%$, (2) The model is good qualifying based on educational technology experts test. As many as $75 \%$ of the learning model has fulfill technologically, (3) The model good qualifying based on individuals test. It shown by $75.46 \%$ of student state that the model can help them to learn, and it allows them to study engineering 
mechanics, (4) The model is good qualifying based on small group trials. After revising some of the shortcomings of the model, then tested back and gained as much as $87.04 \%$ respondents stated that the model meets in study of engineering mechanics, and (5) The model based on the classes trial are found average value of preliminary test $=31.39$; Average value of the final test $=32.04$ ). It shows that the model can improve the students' engineering mechanics learning outcomes.

The effectiveness of model is tested by using the model in five schools in North Sumatra by involving 257 students in calculating equation of pedestal reaction with certain static construction. The same subject matter is taught in three schools not use model by involving 140 students. Powerpoint and guidance sheets are prepared for students in problem-solving steps to calculate equation of pedestal reaction. Based on evaluation stage seems the development of learning model is success. This is seen from the average score obtained by the students that learned with "IS MI QUEEN" model (mean = 77.3) is higher than the average score of which is not taught using models $($ mean $=52.6)$. Futhermore the learning motivation of the students use model is higer than students not use the model. It seems the model developed is effective in improving students' competencies.

\section{Discussion}

The preliminary analysis, theoretical studies and need analysis present needs to be developed the instructional model and the interactive multimedia learning model. The learning model by using interactive multimedia can improve the engineering mechanics learning outcomes. It is in line to Bodemer, Ploetzner,, Bruchmoller, and Hocker (2005). Interactive multimedia can increase the learning motivation of students. The development of the model is done by designing the module learning/ teaching materials through defining the objectives of learning, analysing instructional, identifying students' prior knowledge, determining a criterion-referenced test, determining the learning strategies laid out in the lesson plan, and developing teaching materials. This is in line with the Dick and Carey instructional design. The variety of engineering mechanics sources is used in designing instructional materials, with the aim that students can obtain more information in solving problems in learning. This is the basis for developing the specific structure of the purpose and content, the systems of branching, the label of elements, the symbols used as well as easy to follow and understand by the user (teacher and student).

Based on this, students have a direct control and can interact directly to the resources by using the media. This is in line with Snavely (2012) that state students can control and discuss directly with the group what they need individually or corporately. The teachers also are flexible in interacting with the students and then it became the learning focused on the problem and the subject matter being studied (Chen, Bennett, \& Maton, 2008). Likewise teachers have to master the technique of using internet for searching the information, guiding the students to find sites that are relevant to learning materials, presenting the material through the variety of sources.

The learning outcomes of student of using the model developed is better than students not use. It can be caused by student's learning motivation arise by using media. This is in line with the findings of Gynnild et al. (2007), that the students enjoyed the laboratory demonstrations and computer visualizations on learning mechanics fluid course. Likewise, the findings of Passey and Higgins (2011), stated that the combination of media (video) is better to produce the ability to remember information than any audio or visual presentation of the same material, which just look at the pictures, reading, or listening. Improving the capabilities and productivity can be provided greater benefits by computer technology rather than other technology. Sometimes the capacity of human brain can be exceed by this technology (Cullen et al., 2012). The mechanics simulation make students challenged to understand it. However, teachers and students should be supported with adequate knowledge to use supporting device (Kelly, 2010).

Students' learning outcomes of engineering mechanics who use learning media is better than the students who did not use the media. This shows that the use of media in teaching engineering mechanics can affect brain activity. This is consistent with findings Thomason et al. (2009), developing cognitive function during the learning process can use technology by taking place in involving the learner actively in abundance and cognitive activities. It needed the next study which related to this model because it's still need improvement, especially concerning the understanding of teachers in explaining the topics to be covered in the students. This is important so that students can more easily understand and make sense of learned by them.

\section{Conclusions}

This paper has described the successful of interactive multimedia-based instructional model development which made on the availability of resources, educators need and students need. In this case teachers and students must have ability and a motivation to interact as a condition of the successful use of this model. It is important as well as the support of learning and networking devices. The model uses nine steps, namely: Introduction, Sense, Managing, Interpret, Questioning, Utility, Experimenting, Evaluation and Networking so it's named "IS MI 
QUEEN" model. Each of stage must be done to build a deep knowledge of the subject being taught. It is important so that students learning outcomes is really deep. This model need every school provides trained educators who have high motivation in multimedia-based instructional pattern. It is very useful to support the sustainability of the improvement of learning outcomes that is supported by the availability of learning and networking devices that can be accessible by students in a classroom. In this regard has been obtained that the model contributes to changes in teacher-centered learning paradigm into a student-centered learning.

Educational paradigm developed at this time is students construct their own knowledge through experience gained from interaction with the environment. The roles of teacher change into a facilitator, an evaluator and a motivator. The model is the learning process that utilizes the development of information and communication technology with the philosophy of constructivism. This instructional model makes the process of learning becomes a student-centered learning and adhere to the philosophy of constructivism which is so highly precise as one option to implement the learning process. So It facilitates students so can learn according to their learning needs and their learning styles, and can change the mindset of students who aim to form creative thinking skills that encourages students to learn interactive collaborative both fellow students and to access a variety of quality teaching materials and enables students to learn everywhere and whenever they want.

\section{Acknowledgements}

We would like to thank Ministry of Research and Technology and Higher Education of Indonesia, especially General Directorate of Higher Education, for funding this research.

\section{Refrerences}

Anonymous. (2003). Enhancing instruction with visual media: Utilizing video and lecture capture. IGI Publishing.

Atkinson, C., \& Bostan, P. (2009). Towards a Client-Oriented Model of Types and States in Service-Oriented Development. 2009 IEEE International Enterprise Distributed Object Computing Conference. http://dx.doi.org/10.1109/EDOC.2009.16

Bodemer, D., Ploetzner, R., Bruchmoller, K., \& Hocker, S. (2005). Supporting learning with interactive multimedia through active integration of representations. Instructional Science, 33(1), 73-95. http://dx.doi.org/10.1007/s11251-004-7685-z

Borg, R. W., \& Gall, M. D. (1983). Education research an introduction (4th ed.). New York: Longman.

Boyatzis, R. E. (2008). Competencies in the 21st century. Journal of Management Development, 27, 5-12. http://dx.doi.org/10.1108/02621710810840730

Bridgeland, D. M., \& Zahavi, R. (2009). Creating a Good Model. Business Modeling, 183-212. http://dx.doi.org/10.1016/B978-0-12-374151-6.00007-0

Brinkerhoff, D. A. (2001). Survey of instructional development models, third edition. TECHTRENDS TECH TRENDS, 45(1), 48-50. http://dx.doi.org/10.1007/BF02763388

Cai, Y. (2014). Multimodal interactive teaching and learning in the multimedia environment. Electrical Engineering and Information Technology. http://dx.doi.org/10.2495/CEEIT140351

Chen, R. T., Bennett, S., \& Maton, K. (2008). The adaptation of chinese international students to online flexible learning: Two case studies. Distance Education, 29(3), 307-323. http://dx.doi.org/10.1080/01587910802395821

Cowie. H. (2000). Increasing competence through collaborative problem solving. British Journal of Educational Psychology, 70(1), 144-145. http://dx.doi.org/10.1111/bjep.2000.70.issue-1

Cullen, J., Bramley, D., Armstrong, D., Butler, L., Rouse, P., \& Ashton, T. (2012). Increasing productivity, reducing cost and improving quality in elective surgery in New Zealand: The waitemata district health board joint arthroplasty pilot. Internal Medicine Journal, 42(6), 620-626. http://dx.doi.org/10.1111/j.1445-5994.2012.02815.x

Damiana, M., \& Almei, P. (2012). Multimedia Teaching Contents: Creating and Integrating Activities in New Learning Environments. Interactive Multimedia. http://dx.doi.org/10.5772/35981

Deliyannis, I. (2012). From Interactive to Experimental Multimedia. Interactive Multimedia. http://dx.doi.org/10.5772/38341

Dereshiwsky, M. I. (2014). Building Successful Student Learning Experiences Online. Media Rich Instruction, 
49-66. http://dx.doi.org/10.1007/978-3-319-00152-4_4

Dick, W., \& Carey, L. (1996). The systematic design of instruction (4th ed.). New York: Harper Collins Publishers.

Dooly, M. (2012). Promoting Competency-Based Language Teaching Through Project-Based Language Learning. Educational Linguistics, 77-91. http://dx.doi.org/10.1007/978-94-007-5386-0_5

Educational Ministery of Indonesia. (2006). Towards the development of primary and secondary education management. Jakarta: Director General of Primary and Secondary Education

Gati, I., \& Tal, S. (2008). Decision-Making Models and Career Guidance. International Handbook of Career Guidance, 157-185. http://dx.doi.org/10.1007/978-1-4020-6230-8_8

Gynnild, V., Myrhaug, D., \& Pettersen, B. (2007). Introducing innovative approaches to learning in fluid mechanics: a case study. European Journal of Engineering Education, 32(5), 503-516. http://dx.doi.org/10.1080/03043790701433137

Hammer, J., \& Swaffar, J. (2012). Assessing strategic cultural competency: Holistic approaches to student learning through media. The modern language journal, 96(2), 209-233. http://dx.doi.org/10.1111/j.1540-4781.2012.01335.x

Hicks, P. (2014). Competency 3. Identify and perform appropriate learning activities to guide personal and $\begin{array}{lllll}\text { professional development. } & \text { Academic } & \text { Pediatrics, } & \text { 14(2), } & \text { S42-S43. }\end{array}$ http://dx.doi.org/10.1016/j.acap.2013.11.056

Hoag. (2001). Skills Development for Engineers: innovative model for advanced learning in the workplace. http://dx.doi.org/10.1049/PBMT020E

Hunt, A., Howard, D. M., Kirk, R., Ash, K., \& Tyrrell, A. M. (2001). Interactive multimedia systems for engineering education in acoustics, synthesis and signal processing. European Journal of Engineering Education, 26(2), 91-106. http://dx.doi.org/10.1080/03043790110033574

Juniper, L. (2000). Increasing competence through collaborative problem solving. Teacher Development, 4(2), 305-313. http://dx.doi.org/10.1080/13664530000200288

Kelly, B. (2010). Mechanics simulations in second life. International Journal of Virtual and Personal Learning Environments (IJVPLE), 1(2), 31-44. http://dx.doi.org/10.4018/jvple.2010040103

Kennedy, E. (1999). Increasing Competence through Collaborative Problem Solving. Gerda Hanko. London: David Fulton Publishers (p. 176). Child Psychol. Psychiat. Rev., 4(4), 190-193. http://dx.doi.org/10.1017/S1360641799222058

Köck, M., \& Paramythis, A. (2011). Activity sequence modelling and dynamic clustering for personalized e-learning. User Modeling and User-Adapted Interaction, 21(1-2), 51-97. http://dx.doi.org/10.1007/s11257-010-9087-z

Lewis, L. K. (2011). Applying the Model in Practice. Organizational Change: Creating Change through Strategic Communication (pp. 260-281). http://dx.doi.org/10.1002/9781444340372.ch9

Mahoney, J. L., Cairns, B. D., \& Farmer, T. W. (2003). Promoting interpersonal competence and educational success through extracurricular activity participation. Journal of Educational Psychology, 95(2), 409-418. $\mathrm{http}: / / \mathrm{dx}$.doi.org/10.1037/0022-0663.95.2.409

Mioduser, D., \& Dagan, O. (2007). The effect of alternative approaches to design instruction (structural or functional) on students'mental models of technological design processes. Int J Technol Des Educ, 17, 135-148. http://dx.doi.org/10.1007/s10798-006-0004-z

Moon, J. A. (2004). A handbook and reflective and experiential learning. Theory and Practice. USA: Routledge Falmer,

Morris, T. (2000). Multimedia Interactivity. Applied Computing, 61-73. http://dx.doi.org/10.1007/978-1-4471-0455-1_5

Moss, R. (2006). Learning, Media and Technology-40 years on. Learning, Media and Technology, 31(1), 67-80. http://dx.doi.org/10.1080/17439880500515515

Passey, D., \& Higgins, S. (2011). Learning platforms and learning outcomes - insights from research. Learning, Media and Technology, 36(4), 329-333. http://dx.doi.org/10.1080/17439884.2011.626783 
Putwain, D. W., \& Symes, W. (2011). Achievement goals as mediators of the relationship between competence beliefs and test anxiety. British Journal of Educational Psychology, 82(2), 207-224. http://dx.doi.org/10.1111/j.2044-8279.2011.02021.x

Rychen, D. S. (2002). Key competencies for the knowledge society. A contribution from OECD ProjectDefinition and Selection of Competencies (DeSeCo). Education-Lifelong learning and the Knowledge Economy, Conference in Stuttgart, October 10-11. http://dx.doi.org/10.1007/978-3-642-15378-5

Schippmann, J. S. et al. (2000). The practice of competency modeling. Personnel Psychology, 53, 703-740. http://dx.doi.org/10.1111/j.1744-6570.2000.tb00220.x

Shipton, H., \& Sillince, J. (2012). Organizational learning and emotion: Constructing collective meaning in support of strategic themes. Management Learning, 44(5), 493-510. http://dx.doi.org/10.1177/1350507612450547

Snavely, L. (2012). Student engagement and the academic library. US: Libraries Unlimited Ebooks.

Snook, I. (2001). Lifelong Education: Some Deweyan Themes. International Handbook of Lifelong Learning, 155-164. http://dx.doi.org/10.1007/978-94-010-0916-4_10

Thomason, M. E., Race, E., Burrows, B., Whitfield-Gabrieli, S., Glover, G. H., \& Gabrieli, J. D. E. (2009). Development of spatial and verbal working memory capacity in the human brain. Journal of Cognitive Neuroscience, 21(2), 316-332. http://dx.doi.org/10.1162/jocn.2008.21028

Watkins, R., \& Schlosser, C. (2000). Capabilities-based educational equivalency units: Beginning a professional

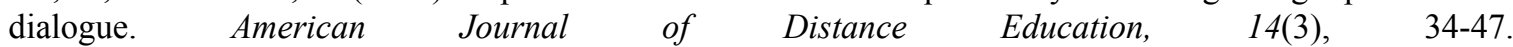
http://dx.doi.org/10.1080/08923640009527063

Xia, S. (2011). Interactive Design Research of Multimedia Courseware in Teaching. Advanced Materials Research, 271-273, 1472-1477. http://dx.doi.org/10.4028/www.scientific.net/AMR.271-273.1472

Young, P. A. (2009). Instructional Design Frameworks and Intercultural Models. USA: University of Maryland, Baltimore County.

\section{Copyrights}

Copyright for this article is retained by the author(s), with first publication rights granted to the journal.

This is an open-access article distributed under the terms and conditions of the Creative Commons Attribution license (http://creativecommons.org/licenses/by/4.0/). 